\title{
Joint Effects of Mexidol and Nitroglycerine on Nitric Oxide Formation in Animal Liver Tissues
}

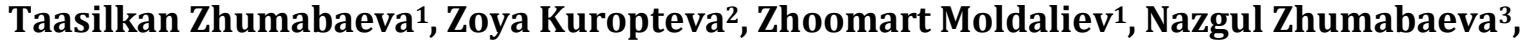 Amanai Kadyrbaeva ${ }^{4}$, Nurbek Bopoev5 ${ }^{5}$ Zhypargul Abdullaeva ${ }^{6 *}$ (1)}

\author{
${ }^{1}$ Department of Natural Sciences, Osh State University, Osh, Kyrgyzstan \\ ${ }^{2}$ Institute of Biochemical Physics, Russian Academy of Sciences, Moscow, Russia \\ ${ }^{3}$ Department of Medicine, Kyrgyz-Turkish University Manas, Bishkek, Kyrgyzstan \\ ${ }^{4}$ Department of Hospital Therapy, Zhalal-Abad State University, Zhalal-Abad, Kyrgyzstan \\ ${ }^{5}$ International Hope School Bangladesh of Gulshan Branch, Dhaka, Bangladesh \\ ${ }^{6}$ Science and Research Department, Osh State University, Osh, Kyrgyzstan \\ Email: *jypar.science@oshsu.kg
}

How to cite this paper: Zhumabaeva, T. Kuropteva, Z., Moldalive, Z., Zhumabaeva, N., Kadyrbaeva, A., Bopoev, N. and Abdullaeva, Z. (2021) Joint Effects of Mexidol and Nitroglycerine on Nitric Oxide Formation in Animal Liver Tissues. American Journal of Molecular Biology, 11, 73-82. https://doi.org/10.4236/ajmb.2021.113007

Received: March 11, 2021

Accepted: June 19, 2021

Published: June 22, 2021

Copyright $\odot 2021$ by author(s) and Scientific Research Publishing Inc. This work is licensed under the Creative Commons Attribution International License (CC BY 4.0). http://creativecommons.org/licenses/by/4.0/

\begin{abstract}
This work is investigating Mexidol (2-ethyl-6-methyl-3-hydroxy pyridine succinate) effect on the formation of nitric oxide (NO) in animal liver tissues, which is a regulator of many physiological processes and plays an important role in the vascular relaxation, neurotransmission and immune system functioning. Analyses performed by EPR spectroscopy revealed Hem-NO complex signals from paramagnetic centers in arbitrary units; produced nitrogen oxide amount in liver tissues was determined by method of double integration signals from nitrosyl complexes.
\end{abstract}

\section{Keywords}

Nitroglycerine, Liver Tissue, Nitric Oxide, Mexidol, Joint Effect, EPR Spectra

\section{Introduction}

Pretreatment with mexidol under conditions of acute liver damage in rats showed inhibition of lipid peroxidation, normalization of enzymes-markers activity in damage of hepatocytes, and normalization of blood serum bilirubin level; mexidol (3-hydroxy-6-methyl-2-ethylpyridine succinate) influences the state of homeostasis in guinea pigs intoxicated with paracetamol [1] [2].

Not so far nitric oxide (NO) has been recognized as an important source in several biological systems in combination with specific enzymes responsible for endogenous NO production in mammalian cells, whereas the biological effect of $\mathrm{NO}$ is dependent on the concentration at the site of action [3]. 
The nature of mexidol and nitroglycerine joint effects on the nitric oxide formation in the liver tissue was unknown until the relaxation factor stimulating the formation of cyclic guanosine monophosphate (cGMP), which serves as a secondary mediator for neurotransmitters and hormones that can influence guanylate cyclase and have a vasodilation effect had been found. Simultaneously, the mechanisms of the blood vessel dilation have been discovered in interaction of acetylcholine with receptors of blood vessel endothelial cells, leading to the formation of small molecules migrating into the muscle layer and causing their relaxation [4]. These molecules are called endothelial relaxation factors (ERF) [5] [6] [7] [8]. The generation of NO by activated macrophages has been studied [9] [10] [11]. It has been found that the cytostatic and cytotoxic effects of macrophages mediated by nitric oxide (NO). When activated by bacterial endotoxins or T-lymphocytes, macrophages activate the synthesis of iNOS enzyme, participating in a pathway converting arginine to nitric oxide. The latter is secreted from macrophages (MF) and quickly penetrates bacteria, fungi, or tumor cells. There, nitric oxide inhibits vital groups of enzymes: the mitochondrial respiratory chain of the Krebs cycle and DNA synthesis. Under these conditions, energy production and cell division become impossible which can lead to cell death.

The beneficial role of nitric oxide (NO) is its circulatory effects and free radical scavenging properties, effect on vascular control including modulation of vascular tone and inflammation under the normal conditions [12].

Individual or combined treatment effect with using mexidol and nitroglycerine on iron-sulfur centers in the mitochondrial respiratory chain, cytochrome $\mathrm{P}-450$ of the endoplasmic reticulum, and nitric oxide formation in the liver tissue was studied [13].

To understand the nature of cytostatic and cytotoxic signals, it is necessary to consider reactions with oxygen and superoxide radicals. The products of these reactions are peroxynitrites and are responsible for the toxic effects of nitrogen oxide (NO). Suppression of aconitase in the Krebs cycle [14], ribonucleotide reductase, interaction with thiols, and depletion of energy reserves currently discussed as possible pathways for cell death.

\section{Research Materials and Methods}

\subsection{In Vitro Experiments on Liver Tissue}

In the experiments, we used mexidol (2-ethyl-6-methyl-3-hydroxypyridine succinate, synthesized at the Institute of Bioorganic Chemistry, Russian Academy of Sciences), at a concentration of $2.5 \times 10^{-3} \mathrm{M}$ in Tris buffer $(\mathrm{pH}=7.2)$ and nitroglycerin $6 \times 10^{-6} \mathrm{M}$ (Institute new technologies of the Russian Academy of Medical Sciences) in a Tris-buffer $(\mathrm{pH}=7.2)$. The objects of the study were the mice liver tissues obtained from the male SHK colony weighing from $20 \pm 2 \mathrm{~g}$, kept under standard vivarium conditions with free access to water and food. In several experiments, C57BL/6 mice lines were used.

In the course of the experiment, the liver was isolated immediately after cer- 
vical dislocation of animals, and washed in saline solution, cut into small pieces, and then incubated with mexidol, nitroglycerin, their mixture, and the Tris-buffer $(\mathrm{pH}=7.2)$ as a control. To all samples, $1 \mathrm{ml}$ of saline solution added. At certain time intervals after the start of incubation at room temperature, tissues were taken out, from which samples for EPR analysis measurements were prepared in the form of columns, $30 \mathrm{~mm}$ in height and $3 \mathrm{~mm}$ in diameter, frozen at $77 \mathrm{~K}$. Animals injected intraperitoneally; four series of experiments were performed in which 5 animals per point were used.

\subsection{EPR Spectra}

EPR spectra measured on X-band ESR 300 spectrometer from Bruker (Germany) equipped with a computer standard program. The use of a computer made it possible to accumulate EPR spectra, subtract, add and double integrate spectra, measure the intensity of signals, their half-width, hyperfine interaction constants, and g-factors. Histograms of changes in signal intensity over time were constructed using the amplitude obtained from the EPR signals of paramagnetic centers in arbitrary units. When constructing the curves, tissue samples from 6 experimental animals were used to determine the paramagnetic centers at each point of the curve. The amount of nitrogen oxide produced in the systems was determined by the method of double integration of signals from nitrosyl complexes.

\subsection{Hem-NO and EPR Reference Signals}

The reference solution was nitroxyl radical 4-(N, N-dimethyldecylamine)-2,2,6,6-tetra-methyl-piperidine-N-oxyl at a concentration of $10^{-5}$. Spectral parameters measured at the same conditions at $77 \mathrm{~K}$. Since the reference solution EPR signal was saturated with increasing microwave power, in the calculations the double integral of the reference was taken with the corresponding correction for saturation.

As an estimate of the statistical spread of the EPR signal intensities of tissue samples from different animals in one series, the standard deviation was used for a confidence interval of $90 \%$. The experimental procedures were carried out following the Helsinki Declaration provisions for human and animal treatment.

\section{Results and Discussions}

In the in vitro experiments, both the direct effect of mexidol on the liver tissue of experimental animals and its combined effect with nitroglycerine (NG) on the state of iron-containing centers (ISCC) of mitochondria and heme-containing proteins in the composition of integral animal tissues were studied.

Analysis of the EPR spectra obtained from liver tissue samples incubated only with Mexidol for $24 \mathrm{~h}$ at room temperature and control samples incubated under the same conditions showed, that NO is also formed in liver tissue samples after incubation with Mexidol (Figure 1). 


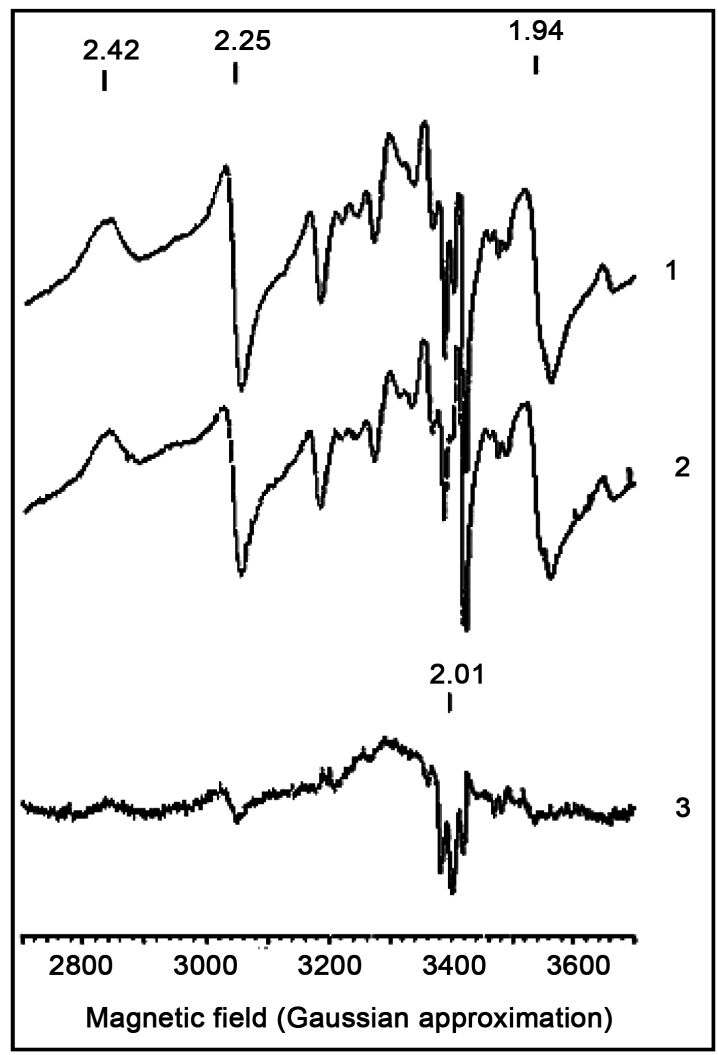

Figure 1. EPR spectra of liver tissue samples incubated for 24 hours at room temperature with Mexidol (1) and saline solution (2). Below (3) shows the difference in the EPR spectrum, obtained by subtracting spectrum 2 from spectrum 1 .

When subtracting the EPR spectra of the control liver samples (Figure 1(2)) from the EPR spectra of the samples incubated in the presence of Mexidol (Figure 1(1)), the signal of Hem-NO complexes recorded (Figure 1(3)). The appearance of this signal indicates formation of nitric oxide in the liver tissues under the action of Mexidol. It is interesting to note that, in experiments with SHK mice line, formation of NO practically not observed in heart tissues without nitroglycerine, whereas for animals of the $\mathrm{C} 57 \mathrm{Bl} / 6$ line, the formation of nitric oxide was observed.

\section{Liver Tissue}

Figure 2 shows the EPR spectra collected from the liver tissue samples, taken 24 $\mathrm{h}$ after the start of incubation with nitroglycerine and mexidol (Figure 2(1)), and nitroglycerine separately (Figure 2(2)). In liver tissue samples after incubation with NG, in addition to the ISCC signals usually observed in the liver of intact animals with a g-factor of $1.94(\mathrm{~N}-1 \mathrm{~b}$ centers of the $\mathrm{NADH}$-dehydrogenase complex of the mitochondrial respiratory chain) and cytochrome P-450 with $\mathrm{g}_{1}=$ 2.42 and $\mathrm{g}_{2}=2.25$, an intense signal was recorded with a characteristic triplet splitting at $g=2.01$. This is a well-known signal, which is due to nitrosyl 


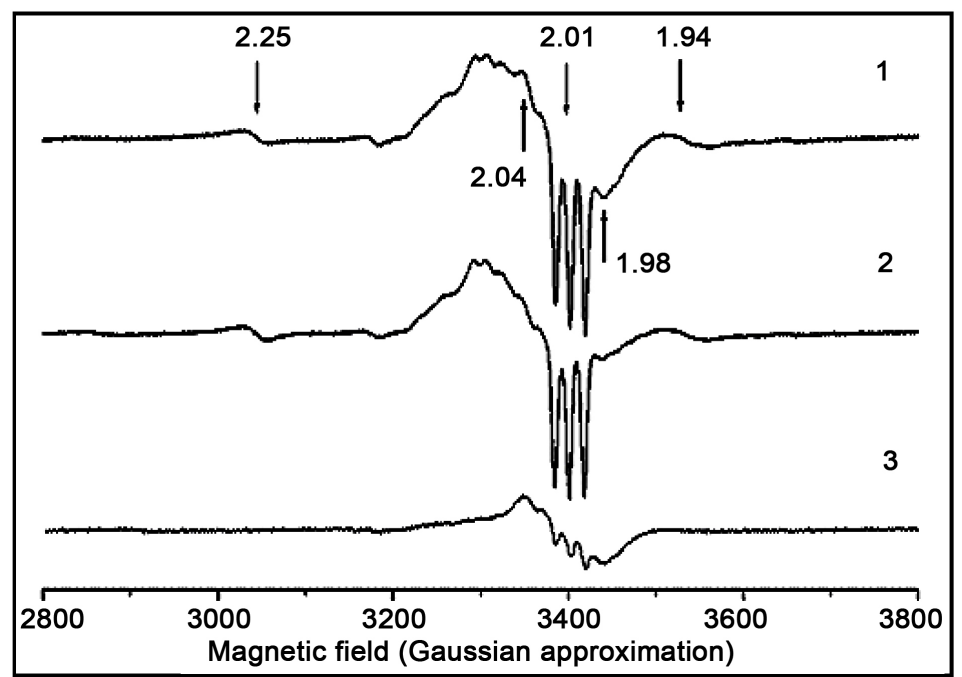

Figure 2. EPR spectra from liver tissue samples were taken 24 hours after the start of incubation with nitroglycerine and mexidol (1), nitroglycerin separately (2). Bottom (3) shows the EPR spectrum obtained by subtracting spectrum 2 from spectrum 1 . Conditions for recording the spectra were: microwave power $20 \mathrm{~mW}$, magnetic field modulation amplitude $5 \mathrm{G}$, temperature $77 \mathrm{~K}$.

complexes of heme iron with nitric oxide Hem-NO [15] [16]. In the EPR spectra of the liver tissue, this signal is due to the presence of nitrosyl complexes of two heme-containing proteins: Hem-NO and cytochrome P-450-NO.

The appearance of Hem-NO complexes is evidence of the well known formation effect of a large amount of NO during the regenerative biotransformation of NG in the body, which was registered for the first time in [17], and then in other works, and is also recorded in tissue homogenates. In the EPR spectra of samples incubated with mexidol and nitroglycerine, the level of complexes due to the binding NO to the R-conformers of hemoglobin (an oxygenated form of hemoglobin) was higher than with nitroglycerine alone.

In Figure 2(1) g-factor components at 2.04 and 1.98 were noted, which belong to the EPR spectrum of nitrosyl complexes of R-conformers of hemoglobin. It was previously shown that hemoglobin molecule in different conformational states interacting with NO resulted in the appearance of EPR spectra different shaped lines.

Figure 2 shows the EPR spectrum obtained by subtracting the spectrum in Figure 2(2) from the spectrum in Figure 2(1). The difference spectrum is entirely due to the Hem-NO nitrosyl complexes. This means that the signal intensity of the Hem-NO complexes in the samples incubated with NG and mexidol together was higher than with NG separately. That is, mexidol contributes to the additional formation of nitric oxide. It should be noted that there are differences in the shape of the EPR spectra of the nitrosyl complexes Hem-NO in Figure 2(1) and Figure 2(2).

When studying the dependence of the EPR spectra for nitrosyl complexes of hemoglobin on the degree of saturation of NO for various subunits and various 
states of hemoglobin, it was found that the alpha chains of the Hem-NO complexes are sensitive to the $\mathrm{R}$ - and $\mathrm{T}$-states of the quaternary structure of hemoglobin [8] [18].

The resulting shape of EPR spectra collected from nitrosyl complexes Hem-NO will be determined by the ratio of oxygenated $-\mathrm{R}$ and non-oxygenated-T-conformers of hemoglobin. The appearance in the EPR spectra after the introduction of mexidol and nitroglycerin component complex at g-factors of 2.04 and 1.98 in Figure 2(1) indicates an increase in the proportion of complexes due to the oxygenated form of hemoglobin. These data indicate that the presence of mexidol contributes to the increase in the degree of hemoglobin oxygenation.

Figure 3 is showing the EPR spectra taken from liver tissue samples in mice after 30 min start of incubation with saline solution (1); mexidol at a concentration of $2.5 \times 10^{-3} \mathrm{M}(2)$; and nitroglycerin at a concentration of $6 \times 10^{-6} \mathrm{M}$ (3). As it can be seen, in liver tissue samples after incubation with NG, in addition to the signals usually observed in the liver of intact animals with a g-factor of 1.94 (center of the N-1b NADH-dehydrogenase complex) and cytochrome P-450 with $\mathrm{g}=2.42$ and $\mathrm{g}=2.25$, an intense signal of nitrosyl complexes of heme-NO was recorded (Figure 4) with characteristic triplet splitting at $g=2.01$ [17]. In the EPR spectra of the liver, due to the presence of nitrosyl complexes of two heme-containing proteins, Hem-NO and cytochrome P-450-NO were observed. The appearance of Hem-NO complexes is indicating formation of a large amount of NO during the biotransformation of NG. The intensity of the EPR signal of the ISCC during incubation of liver tissues for $26 \mathrm{~h}$ at room temperature with mexidol at a concentration of $2.5 \times 10^{-3} \mathrm{M}$, and with NG at a concentration of $6 \times 10^{-6} \mathrm{M}$, and their complex decreased further. The largest decrease at a factor of 3.4 is associated with the oxidation of the ISCC, which occurred in the presence of NG.

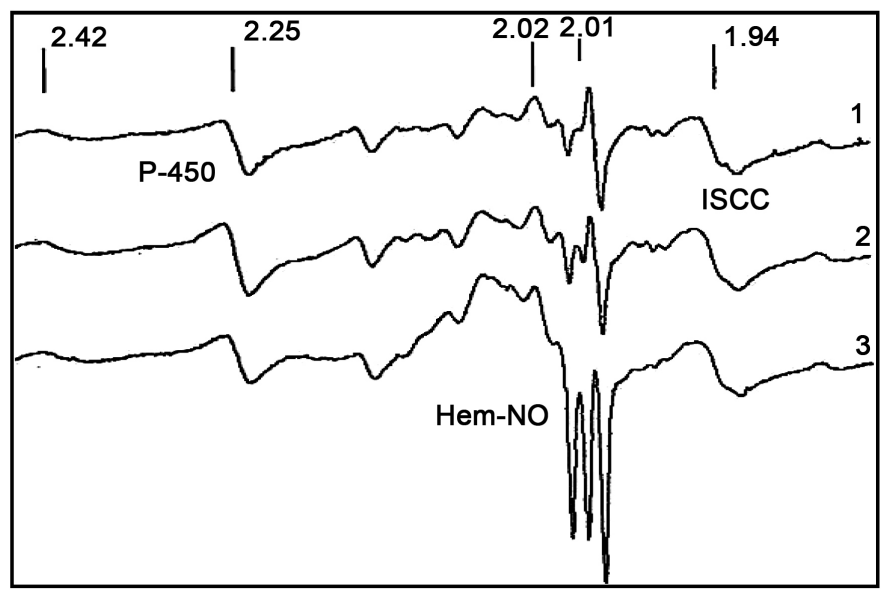

Figure 3. EPR spectra of liver tissue samples from mice taken 30 min after the start of incubation with saline (1); Mexidol at a concentration of $2.5 \times 10^{-3} \mathrm{M}(2)$; Nitroglycerin at a concentration of $6 \times 10^{-6}(3)$. Spectrum recording conditions: microwave power 20 $\mathrm{mW}$, magnetic field modulation amplitude $5 \mathrm{G}$, temperature $77 \mathrm{~K}$. 
(a) ISCC

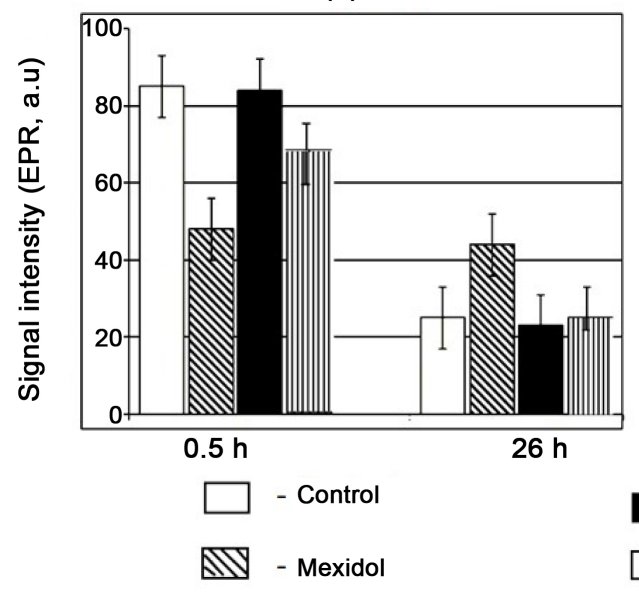

(b) Hem-NO

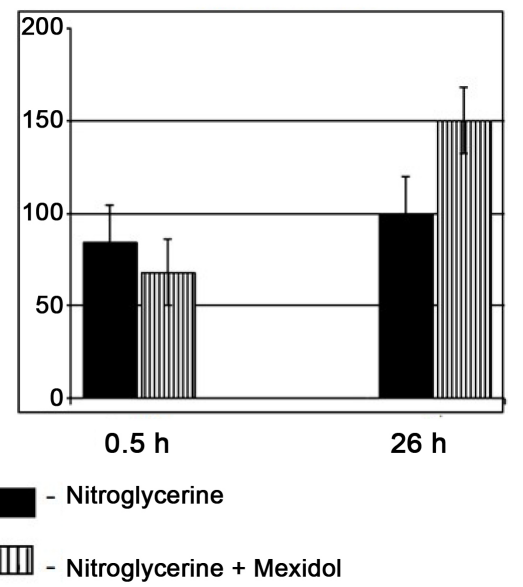

Figure 4. Intensity signals of EPR during incubation of liver tissues with mexidol $(2.5 \times$ $\left.10^{-3} \mathrm{M}\right)$, nitroglycerine $\left(6 \times 10^{-6} \mathrm{M}\right)$, and their combined actions. (a) Iron-sulfur containing centers; (b) Hem-NO.

The use of a mexidol in combination with nitroglycerine also promoted the oxidation of ISCC, although to a lesser extent the activity of the ISCC decreased 2.9 times. After $26 \mathrm{~h}$ of incubation with Mexidol, the activity of the ISCC decreased by only 1.2 times, in the control sample by 3 times. The use of mexidol alone protected the ISCC from oxidation, and the intensity of the ISCC signal after $26 \mathrm{~h}$ incubation of liver tissues with mexidol was 1.5 times higher than in the control.

The data obtained is indicating the ability of mexidol to protect the ISCC of the mitochondrial respiratory chain from oxidation, including that induced by NG, supporting the functioning of mitochondrial electron transport chain and, consequently, the energy supply of cells. The signal intensity of the Hem-NO complexes increased with time: 1.5 times after $26 \mathrm{~h}$ of incubation in the presence of NG; 2.8 times in the presence of mexidol and NG (Figure 4).

Consequently, the amount of NO formed in the liver tissues was higher when mexidol was used. Analysis of the EPR spectra of samples incubated with mexidol and control samples incubated under the same conditions showed, that NO was formed in liver tissue samples after incubation in the presence of mexidol.

Based on the obtained data, it can be assumed, that observed increase in NO production under the action of mexidol (Figure 2) might be related precisely to its properties as a reducing agent due to one of its constituent parts, hydroxypyridine part of the mexidol molecule.

In liver tissues, almost all cells are capable of expressing iNOS hepatocytes, Kupffer cells, endothelial cells, Ito cells; therefore, the increase in NO production in liver tissues will be higher and more easily observed comparing to heart tissues. Mexidol can also affect the activity of iNOS in vascular endothelial cells since in these cells inducible iNOS also functions in addition to constitutive endothelial NO synthase. Intensity changes in iron-sulfur proteins signals and Hem-NO nitrosyl complexes shown in Table 1 and Table 2. 
Table 1. Intensity change signals in iron-sulfur proteins.

\begin{tabular}{cccc}
\hline \multicolumn{2}{c}{ Nitroglycerine } & \multicolumn{2}{c}{ Mexidol + NG } \\
\hline $0.5 \mathrm{~h}$ & $26 \mathrm{~h}$ & $0.5 \mathrm{~h}$ & $26 \mathrm{~h}$ \\
82 & 104 & 67 & 160 \\
79 & 95 & 63 & 154 \\
86 & 97 & 72 & 151 \\
80 & 100 & 70 & 156 \\
$81.8 \pm 3.1$ & $99 \pm 3.9$ & $68 \pm 3.9^{* *}$ & $155 \pm 3.8^{* *}$ \\
\hline
\end{tabular}

Mexidol compared to control $\mathrm{p}=0.021,\left({ }^{* *} \mathrm{p}<0.05\right)$. Mexidol and Mexidol $+\mathrm{NG} \mathrm{p}=0.020$

Table 2. Intensity change signals in nitrosyl complexes Hem-NO.

\begin{tabular}{ccccc}
\hline Liver control & Liver control & Mexidol & Nitroglycerine & Mexidol + NG \\
\hline \multicolumn{5}{c}{ 26 hours } \\
83 & 28 & 42 & 24 & 25 \\
87 & 25 & 46 & 18 & 21 \\
84 & 26 & 39 & 22 & 23 \\
79 & 21 & 45 & 23 & 24 \\
$83.25 \pm 3.3$ & $25 \pm 2.9$ & $43 \pm 3.2^{* *}$ & $21.8 \pm 2.6$ & $23.3 \pm 1.7^{* *}$ \\
\hline
\end{tabular}

Note: for signals of $26 \mathrm{~h}$ with NG compared to Mexidol + NG p $=0.0208$ p.a.; ${ }^{* *} \mathrm{p}<0.05$. In the control samples at $0.5 \mathrm{~h}$, no signals of the hemoglobin nirosyl complexes observed.

The indicated concentrations of mexidol and nitroglycerin (NG) are consistent with their clinical use. A decrease in the oxidation of iron-sulfur proteins in the presence of nitroglycerin (approximately 3.4 times) can be noted. In combined action of Mexidol with nitroglycerine, it was noted that activity of these proteins is decreasing to 2.9 times. $a$ is decrease in ICP observed by 1.2 times; simultaneously, during incubation with Mexidol for 26 hours, in the control samples, activity of these proteins decreased by 3 times; $b$ is change in intensity of the Hem-NO signal in liver tissues incubated with NG and NG + Mexidol for 0.5 and $26 \mathrm{~h}$ at room temperature, respectively. As can be seen from Table 2 and Figure 4, in the presence of NG, the signal intensity of nitrosyl complexes Hem-NO increases to 1.5 times, and in the joint incubation with Mexidol increases to 2.8 times.

\section{Conclusion}

In summary, the results of experimental studies have shown that mexidol exhibits a multifaceted positive effect, when used alone and when combined with nitroglycerine: it increases the yield of NO, which promotes vascular relaxation. In addition, in clinical use, this action of mexidol can reduce the dose of nitroglycerine. Mexidol reduces the negative effect of nitroglycerine on mitochondria, protecting the LSC from oxidation, and increases the degree of hemoglobin 
oxygenation.

\section{Ethical Statement}

Experiments performed in accordance with the provisions of the Helsinki Declaration for human and animal treatment.

\section{Conflicts of Interest}

The authors declare no conflicts of interest regarding the publication of this paper.

\section{References}

[1] Deviatkina, T.A., Lutsenko, R.V. and Vazhnichaia, E.M. (2003) Pharmacological Activity of Mexidol in the Stress-Induced Liver Damage. Eksperimental naia i klinicheskaia farmakologiia, 66, 56-58.

[2] Katikova, O. (2002) Effect of Mexidol on the Homeostasis and Lipid Peroxidation in Paracetamol Poisoning. Eksperimental naia i klinicheskaia farmakologiia, 65, 53-56.

[3] Agvald, P., Adding, L.C., Artlich, A., Persson, M.G. and Gustafsson, L.E. (2002) Mechanisms of Nitric Oxide Generation from Nitroglycerin and Endogenous Sources during Hypoxia in Vivo. British Journal of Pharmacology, 135, 373-382. https://doi.org/10.1038/sj.bjp.0704489

[4] Furchgott, R. and Zawadzki, J. (1980) The Obligatory Role of Endothelial Cells in the Relaxation of Arterial Smooth Muscle by Acetylcholine. Nature, 288, 373-376. https://doi.org/10.1038/288373a0

[5] Ignarro, L.J., Buga, G.M., Wood, K.S., Byrns, R.E. and Chaudhuri, G. (1987) Endothelium-Derived Relaxing Factor Produced and Released from Artery and Vein Is Nitric Oxide. Proceedings of the National Academy of Sciences of the United States of America, 84, 9265-9269. https://doi.org/10.1073/pnas.84.24.9265

[6] Ignarro, L.J. (1990) Biosynthesis and Metabolism of Endothelium-Derived Nitric Oxide. Annual Review of Pharmacology and Toxicology, 30, 535-560.

https://doi.org/10.1146/annurev.pa.30.040190.002535

[7] Ignarro, L.J. (1990) Nitric Oxide. A Novel Signal Transduction Mechanism for Transcellular Communication. Hypertension, 16, 477-483.

https://doi.org/10.1161/01.HYP.16.5.477

[8] Davies, S.A., Stewart, E.J., Huesmann, G.R., Skaer, N.J., Maddrell, S.H., Tublitz, N.J. and Dow, J.A. (1997) Neuropeptide Stimulation of the Nitric Oxide Signaling Pathway in Drosophila melanogaster Malpighian Tubules. The American Journal of Physiology, 273, R823-R827. https://doi.org/10.1152/ajpregu.1997.273.2.R823

[9] Nathan, C.F. (1983) Mechanisms of Macrophage Antimicrobial Activity. Transactions of the Royal Society of Tropical Medicine and Hygiene, 77, 620-630. https://doi.org/10.1016/0035-9203(83)90190-6

[10] Palmieri, E.M., McGinity, C., Wink, D.A. and McVicar, D.W. (2020) Nitric Oxide in Macrophage Immunometabolism: Hiding in Plain Sight. Metabolites, 10, 429. https://doi.org/10.3390/metabo10110429

[11] Xue, Q., Yan, Y., Zhang, R. and Xiong, H. (2018) Regulation of iNOS on Immune Cells and Its Role in Diseases. International Journal of Molecular Sciences, 19, 3805. https://doi.org/10.3390/ijms19123805

[12] Mahmoud, M.F., Zakaria, S. and Fahmy, A. (2015) Can Chronic Nitric Oxide Inhi- 
bition Improve Liver and Renal Dysfunction in Bile Duct Ligated Rats? Advances in Pharmacological and Pharmaceutical Sciences, 2015, Article ID: 298792. https://doi.org/10.1155/2015/298792

[13] Belaya, O.L., Baider, L.M. and Kuropteva, Z.V. (2006) Effect of Mexidol and Nitroglycerine on Iron-Sulfur Centers, Cytochrome P-450, and Nitric Oxide Formation in Liver Tissue of Experimental Animals. Bulletin of Experimental Biology and Medicine, 142, 422-424. https://doi.org/10.1007/s10517-006-0382-y

[14] Lushchak, O.V., Piroddi, M., Galli, F. and Lushchak, V.I. (2014) Aconitase Post-Translational Modification as a Key in Linkage between Krebs Cycle, Iron Homeostasis, Redox Signaling, and Metabolism of Reactive Oxygen Species. Redox Report, 19, 8-15. https://doi.org/10.1179/1351000213Y.0000000073

[15] Kuropteva, Z.V. (1985) Changes in the Paramagnetic Complexes of Blood and Liver of Animals under the Influence of Nitroglycerin. Reports of the Academy of Sciences of the USSR, 281, 189-192.

[16] Zhumabayeva, T.Z. and Kuropteva, V. (1986) Molecular Mechanisms of the Radiosensitizing Action of Nitro Compounds. Radiobiology, 26, 671-674.

[17] Belaya, O.L., Fomina, I.G., Bider, L.M. and Kuropteva, Z.V. (2006) Iron Sulfur Centers, cit P-450 and the Formation of Nitric Oxide in Liver Tissues of Animals under the Action of Mexidol and Nitroglycerin. Bulletin of Experimental Biology and Medicine, 142, 403-406. https://doi.org/10.1007/s10517-006-0382-y

[18] Palmer, R.M., Ferrige, A.G. and Moncada, S. (1987) Nitric Oxide Release Accounts for the Biological Activity of Endothelium-Derived Relaxing Factor. Nature, 327, 524-526. https://doi.org/10.1038/327524a0 